\title{
Niepodatkowe należności budżetowe a prawo unijne
}

\section{Wprowadzenie}

Z dniem 1 maja 2004 r. Rzeczpospolita Polska stała się członkiem struktur europejskich, a tym samym wspólnotowy (unijny) porządek prawny stał się częścią polskiego porządku prawnego. Polska poprzez podpisanie i ratyfikowanie traktatu akcesyjnego została zobowiązana do dostosowania wewnętrznych regulacji prawnych, również w zakresie prawa daninowego, do norm i wymogów europejskich $\mathrm{w}$ zakresie uregulowanym $\mathrm{w}$ aktach prawa pierwotnego i wtórnego.

$\mathrm{Z}$ treści art. 5 ust. 2 pkt 1 ustawy z dnia 27 sierpnia 2009 r. ${ }^{1}$ o finansach publicznych (dalej: u.f.p.) wynika, że daninami publicznymi w Polsce są: „,podatki, składki, opłaty, wpłaty z zysku przedsiębiorstw państwowych i jednoosobowych spółek Skarbu Państwa, a także inne świadczenia pieniężne, których obowiązek ponoszenia na rzecz państwa, jednostek samorządu terytorialnego, państwowych funduszy celowych oraz innych jednostek sektora finansów publicznych wynika z odrębnych ustaw". W przepisach ustawy z dnia 29 sierpnia 1997 r. ${ }^{2}$ Ordynacja podatkowa (dalej: o.p.) polski ustawodawca określił jeszcze jedną grupę świadczeń publicznoprawnych, tj. niepodatkowe należności budżetowe, które zdefiniowano w art. 3 pkt 8 o.p. jako „niebędące podatkami i opłatami należności stanowiące dochód budżetu państwa lub budżetu jednostki samorządu terytorialnego, wynikające ze stosunków publicznoprawnych"3, a w art. 60 u.f.p. określony został otwarty katalog ww. świadczeń publicznoprawnych ${ }^{4}$.

* Mgr Michał Kowalski - Katedra Prawa Finansowego, Wydział Prawa i Administracji, Uniwersytet im. Adama Mickiewicza w Poznaniu.

${ }^{1}$ Dz. U. 2009 r. Nr 157, poz. 1940.

2 Dz. U. z 1997 r. Nr 137, poz. 926, t.j. Dz. U. z 2005 r. Nr 8, poz. 60 ze zm.

${ }^{3}$ Definicja ta obarczona jest błędem ignotum per ignotum poprzez definiowanie instytucji niepodatkowych należności budżetowych przez instytucję opłaty, która nie posiada definicji legalnej. Definicja zawierająca określenie niezdefiniowane nie może w sposób prawidłowy wyjaśniać omawianej instytucji prawa daninowego.

${ }^{4}$ Są to: kwoty dotacji podlegające zwrotowi w przypadkach określonych w u.f.p., należności z tytułu gwarancji i poręczeń udzielonych przez Skarb Państwa i jednostki samorządu terytorialnego, wpłaty nadwyżek środków obrotowych samorządowych zakładów budżetowych, wpłaty 
Z zamętu prawodawczego wyłania się obraz polskich danin publicznych, do których zaliczyć należy daniny podatkowe i niepodatkowe. Do danin podatkowych należą podatki, natomiast do danin niepodatkowych - niepodatkowe należności budżetowe oraz daniny pozabudżetowe (niestanowiące dochodów budżetu państwa lub jednostek samorządu terytorialnego). Przez niepodatkowe należności budżetowe należy rozumieć wynikające ze stosunków publicznoprawnych świadczenia pieniężne, bezzwrotne, przymusowe i ekwiwalentne, stanowiące dochód budżetu państwa lub budżetów jednostek samorządu terytorialnego, których obowiązek uiszczenia przez podmiot prowadzący działalność zgodną z porządkiem prawnym związany jest z wykonaniem usługi, dostarczeniem towaru, działaniem organu władzy publicznej lub jest sankcją administracyjną nałożoną na podmiot zobowiązany za nieprzestrzeganie postanowień prawa publicznego.

\section{Kompetencje Rzeczypospolitej i Unii Europejskiej w zakresie danin publicznych}

Uprawnienie organów państwa do stanowienia oraz pobierania danin publicznych wynika z art. 84 i art. 217 Konstytucji Rzeczypospolitej Polskiej z dnia 2 kwietnia 1997 r. ${ }^{5}$ (dalej: Konstytucja RP), z których wynika zasada władztwa daninowego państwa. Konstytucyjne istnienie tej zasady jest podstawowym źródłem praw podmiotu publicznego do nakładania danin na podmioty znajdujące się na obszarze imperium danego podmiotu publicznoprawnego ${ }^{6}$. Jurysdykcja państwa w kwestii daninowej oznacza pierwotną suwerenność państwa, która pozostaje nieograniczona $\mathrm{w}$ aspekcie wewnętrznym i zewnętrznym. Warunkiem sine qua non występowania jurysdykcji daninowej jest wystąpienie pełnej suwerenności daninowej ${ }^{7}$, której zasadniczy przejaw następuje w wyznaczeniu wyłącz-

nadwyżek środków finansowych agencji wykonawczych, wpłaty środków z tytułu rozliczeń realizacji programów przedakcesyjnych, należności z tytułu zwrotu płatności dokonanych $\mathrm{w}$ ramach programów finansowanych z udziałem środków europejskich, dochody pobierane przez państwowe i samorządowe jednostki budżetowe na podstawie odrębnych ustaw oraz pobrane przez jednostkę samorządu terytorialnego dochody związane z realizacją zadań z zakresu administracji rządowej oraz innych zadań zleconych jednostkom samorządu terytorialnego odrębnymi ustawami i nieodprowadzone na rachunek dochodów budżetu państwa.

${ }^{5}$ Dz. U. z 1997 r. Nr 78, poz. 483 ze zm.

${ }^{6}$ Por. szerzej: T. Dębowska-Romanowska, Istota i treść władztwa finansowego - samowola finansowa (samowola podatkowa), restrykcje finansowe - zagadnienia pojęciowe, [w:] T. Dębowska-Romanowska, A. Jankiewicz (red.), Konstytucja, ustrój, system finansowy państwa. Księga pamiątkowa ku czci prof. Natalii Gajl, Warszawa 1999, s. 345-360.

7 Por. A. Biegalski, Pojęcie i zakres jurysdykcji podatkowej państwa, „Kwartalnik Prawa Podatkowego" 1999, nr 1, s. 89-105. 
nej kompetencji parlamentu do nakładania danin publicznych na drodze ustawy spełniającej szczególne wymogi ${ }^{8}$.

Celem polityki unijnej w zakresie prawa daninowego jest doprowadzenie do harmonizacji przepisów państw członkowskich odnośnie do danin publicznych, które mają wpływ na ustanowienie i funkcjonowanie rynku wewnętrznego, a w jego ramach swobód: przepływu towarów, osób, usług i kapitału, jak również uniknięcie zakłóceń konkurencji. Zasadnicza funkcja prawa daninowego Unii Europejskiej będzie się zatem sprowadzać do zapewnienia rozwoju rynku wewnętrznego i związanych z tym innych aspektów funkcjonowania Unii Europejskiej, tj. swobód traktatowych oraz unikania zakłóceń konkurencji. Unijne prawo daninowe i prawo daninowe poszczególnych państw członkowskich stanowią istotny instrument realizacji celów, jakie stawia sobie Unia Europejska, a które określone są w Traktacie o Unii Europejskiej i Traktacie o funkcjonowaniu Unii Europejskiej ${ }^{9}$. Funkcjonowanie unijnego prawa daninowego ma charakter subsydiarny oraz harmonizacyjny w zakresie, który wpływa na funkcjonowanie rynku wewnętrznego i swobód traktatowych ${ }^{10}$. Unia Europejska przez fakt regulowania prawa daninowego w sposób subsydiarny nie prowadzi do ograniczenia władztwa daninowego państw.

Przepisy Konstytucji RP określają reguły odnoszące się do relacji pierwszeństwa przepisów krajowych oraz przepisów prawa międzynarodowego, w tym także prawa unijnego. Zgodnie z treścią art. 91 ust. 1 Konstytucji RP „Ratyfikowana umowa międzynarodowa, po jej ogłoszeniu w Dzienniku Ustaw Rzeczypospolitej Polskiej, stanowi część krajowego porządku prawnego i jest bezpośrednio stosowana, chyba że jej stosowanie jest uzależnione od wydania ustawy". Natomiast ust. 2 art. 91 Konstytucji RP stanowi, że „Umowa międzynarodowa ratyfikowana za uprzednią zgodą wyrażoną w ustawie ma pierwszeństwo przed ustawą, jeżeli ustawy tej nie da się pogodzić z umową". Stosownie natomiast do treści art. 91 ust. 3 Konstytucji RP ,Jeżeli wynika to z ratyfikowanej przez Rzeczpospolitą Polską umowy konstytuującej organizację międzynarodową, prawo przez nią stanowione jest stosowane bezpośrednio, mając pierwszeństwo w przypadku kolizji z ustawami". W doktrynie prawa polskiego słusznie zauważono ${ }^{11}$, iż cytowane

${ }^{8}$ C. Kosikowski, Finanse publiczne w świetle Konstytucji RP oraz orzecznictwa Trybunału Konstytucyjnego, Warszawa 2004, s. 203.

9 W. Nykiel, Wyktadnia prawa podatkowego wewnętrznego, międzynarodowego i prawa podatkowego Unii Europejskiej (wybrane zagadnienia), „Kwartalnik Prawa Podatkowego” 2004, nr 4, s. 133.

10 T. L. Krawczyk, Co Unia Europejska ma do powiedzenia w sprawach podatków? (cz. I), „Prawo i Podatki Unii Europejskiej” 2005, nr 2, s. 2.

${ }^{11}$ S. Biernat, Miejsce prawa pochodnego Wspólnoty Europejskiej w systemie konstytucyjnym Rzeczypospolitej Polskiej, [w:] C. Mik (red.), Konstytucja Rzeczypospolitej Polskiej z 1997 roku a czlonkostwo Polski w Unii Europejskiej. IV Ogólnopolska Konferencja Prawnicza, Toruń 19-20 listopada 1998 r., Toruń 1999, s. 173-174. 
wyżej przepisy znajdują również zastosowanie w odniesieniu do prawa unijnego - przepis art. 91 ust. 1 i 2 odnosi się do pierwotnego prawa unijnego rozumianego jako umowa międzynarodowa, natomiast art. 91 ust. 3 Konstytucji RP odnosi się do pochodnego prawa unijnego, pojmowanego jako prawo stanowione przez organizację międzynarodową. Unijna dyrektywa z zakresu prawa daninowego będzie miała pierwszeństwo w stosowaniu przed przepisami krajowymi w sytuacji kolizji norm prawa krajowego i unijnego. Obowiązek stosowania pochodnego prawa unijnego dotyczy zarówno organów administracji publicznej, jak i władzy sądowniczej ${ }^{12}$. Naczelny Sąd Administracyjny w wyroku z dnia 2 kwietnia 2009 r. ${ }^{13}$ (sygn. akt I FSK 4/08) wskazał, że „,zastosowanie prawa wspólnotowego w sprawach podatkowych nie jest obowiązkiem tylko sądów administracyjnych, ale także organów władzy państwa, czyli organów podatkowych. Wynika to z faktu, że organy podatkowe mają obowiązek przestrzegania prawa i działania $\mathrm{w}$ jego granicach, czyli również w granicach prawa wspólnotowego".

Przepisy Traktatu o Unii Europejskiej (TUE) i Traktatu o funkcjonowaniu Unii Europejskiej (dalej: TFUE) ${ }^{14}$ określają dziedziny, w których Unia posiada kompetencję wyłączną (art. 3 TFUE), jak również kompetencje dzielone z państwami członkowskimi (art. 4 TFUE), a także w których może podejmować działania o wymiarze europejskim (art. 6 TFUE), lecz nie wskazują w żadnej z wymienionych dziedzin kompetencji Unii Europejskiej w zakresie stanowienia danin publicznych. Unia Europejska nie posiada zatem władztwa daninowego, o jakim stanowią np. przepisy polskiej Konstytucji, a które jest przymiotem suwerennej władzy publicznej ${ }^{15}$.

Brak bezpośredniego odniesienia do regulacji prawa daninowego jako dziedziny znajdującej się w zakresie kompetencji Unii Europejskiej nie oznacza, że przepisy Traktatów nie zawierają postanowień odnoszących się do danin publicznych. Niemniej jednak polityka Unii Europejskiej w sprawach danin publicznych nie stanowi autonomicznych rozwiązań, lecz służy realizacji zasadniczych celów, dla których Unia Europejska powstała. W Części trzeciej, w Tytule VII TFUE zostały określone „Wspólne reguły w dziedzinie konkurencji, podatków i zbliżania ustawodawstwa". Zgodnie z regulacją art. 113 TFUE polityka unijna w zakresie danin publicznych odnosi się do podatków obrotowych, akcyzy i innych podatków pośrednich, a sposobem realizacji tej polityki jest harmonizacja ustawodawstw państw unijnych poprzez implementację stosownych przepisów

${ }_{12}$ M. Safjan, Konstytucja a członkostwo Polski w Unii Europejskiej, „Państwo i Prawo” 2001, nr 3, s. 13 .

13 LEX nr 497204.

${ }^{14}$ Brzmienie przepisów Traktatu o Unii Europejskiej i Traktatu o funkcjonowaniu Unii Europejskiej oparte na publikacji: Prawo Unii Europejskiej. Zbiór aktów prawnych. Edycja sądowa, wyd. 2, Warszawa 2010.

${ }_{15}$ P. Selera, Międzynarodowe a unijne prawo podatkowe w kontekście opodatkowania zysków przedsiębiorstw, Warszawa 2010, s. 151. 
unijnych do narodowych systemów prawnych. Druga istotna zasada wyrażona w art. 113 TFUE stanowi, że działania Unii Europejskiej w dziedzinie prawa daninowego mają $\mathrm{z}$ jednej strony zapewnić ustanowienie i funkcjonowanie rynku wewnętrznego, $\mathrm{z}$ drugiej natomiast uniknięcie zakłóceń konkurencji.

Harmonizacja ustawodawstw państw unijnych w zakresie danin publicznych może również nastąpić w oparciu o art. 115 TFUE, którego regulacja udziela Unii Europejskiej kompetencji do podjęcia działań zmierzających do zbliżania ustawodawstw państw członkowskich w zakresie prawa daninowego, o ile indywidualne regulacje poszczególnych państw bezpośrednio wpływają na ustanowienie lub funkcjonowanie rynku wewnętrznego.

$\mathrm{Na}$ podstawie postanowień Traktatu o funkcjonowaniu Unii Europejskiej państwa członkowskie zobowiązane są do przestrzegania zakazu dyskryminacji podatkowej, który wynika z art. 110 TFUE, a postanowienia tam zawarte posiadają walor bezpośredniej skuteczności. W wyroku Europejskiego Trybunału Sprawiedliwości z dnia 8 lipca 1965 r. ${ }^{16}$ (sygn. akt 10/65) skład orzekający, interpretując pojęcie ,podatku” zwrócił uwagę, że pojęcie to na gruncie przepisów wspólnotowych nie może być rozumiane wąsko i oznaczać jedynie instytucji podatku sensu stricto. Według stanowiska sędziów pojęcie podatku, o którym mowa w obecnym art. 110 TFUE, oznacza wszelkiego rodzaju opodatkowania, a zatem należy przyjąć, iż na gruncie indywidualnych rozwiązań prawnodaninowych państw członkowskich art. 110 TFUE odnosić się będzie do podatkowych i niepodatkowych instytucji daninowych. W związku z powyższym na gruncie prawa polskiego rozwiązania art. 110 TFUE znajdą zastosowanie w stosunku do podatków, jak i niepodatkowych należności budżetowych, których zadaniem byłoby różnicowanie podmiotów krajowych i zagranicznych pod względem obciążeń daninowych. Przedmiotowa kwestia dotyczy obciążeń daninowych, które bezpośrednio odnosiłyby się do różnicowania podmiotów krajowych i zagranicznych, jak również świadczeń publicznoprawnych, których funkcjonowanie w systemie danin publicznych w sposób niebezpośredni prowadziłoby do tego typu zróżnicowania. Natomiast w wyroku z dnia 29 kwietnia 2004 r. ${ }^{17}$ (sygn. akt C-338/01) skład orzekający Europejskiego Trybunału Sprawiedliwości stwierdził, że termin „przepisy podatkowe” należy interpretować jako obejmujący nie tylko przepisy określające podatników, transakcje podlegające opodatkowaniu, podstawę opodatkowania oraz stawki i zwolnienia podatkowe w podatkach bezpośrednich i pośrednich, ale również te postanowienia, które odnoszą się do warunków poboru takich podatków. Sędziowie w cytowanym wyroku wskazali również, że termin ,przepisy podatkowe” obejmuje „nie tylko wszystkie dziedziny podatków,

${ }^{16} \mathrm{http}: / /$ eur-lex.europa.eu/LexUriServ/LexUriServ.do?uri=CELEX:61965J0010:EN:PDF (dostęp: 8.04.2011).

${ }^{17} \mathrm{http} / /$ eur-lex.europa.eu/LexUriServ/LexUriServ.do?uri=CELEX:62001J0338:EN:HTML (dostęp: 17.04.2011). 
bez wprowadzania rozróżnienia rodzajów podatków lub opłat, lecz także wszystkie zagadnienia z tego zakresu, bez względu na to, czy odnosi się to do przepisów materialnych, czy też proceduralnych" ${ }^{\prime 18}$.

\section{Dodatkowe zobowiązanie podatkowe w ustawie o podatku od towarów i usług}

Jednym z zasadniczych zadań instytucji działających na rzecz integracji europejskiej była harmonizacja ustawodawstw państw członkowskich w zakresie podatków pośrednich jako tych, które mogą w sposób znaczący wpływać na funkcjonowanie rynku wewnętrznego. Działaniem zmierzającym do wprowadzenia jednolitej formy opodatkowania towarów i usług na terenie krajów tworzących Europejską Wspólnotę Gospodarczą było przyjęcie Pierwszej Dyrektywy Rady z dnia 11 kwietnia 1967 r. ${ }^{19} \mathrm{w}$ sprawie harmonizacji ustawodawstw państw członkowskich dotyczących podatków obrotowych 67/227/EWG. Zmiany w konstrukcji podatku od wartości dodanej na przestrzeni lat oraz konieczność dostosowania do współczesnych realiów doprowadziła do opublikowania dyrektywy 2006/112/ WE Rady z dnia 28 listopada $2006 \mathrm{r}^{20}$ w sprawie wspólnego systemu podatku od wartości dodanej. Obowiązuje ona od dnia 1 stycznia 2007 r. i stanowi aktualnie podstawowy akt normatywny prawa unijnego odnoszący się do podatku od wartości dodanej ${ }^{21}$.

Polska, będąc członkiem Wspólnot Europejskich, jest zobowiązana do implementacji przepisów unijnych odnoszących się do rozwiązań wspólnotowych. $\mathrm{W}$ tym celu została przyjęta ustawa $\mathrm{z}$ dnia 11 marca $2004 \mathrm{r}^{22} \mathrm{o}$ podatku od towarów i usług (dalej: ustawa o VAT) zastępująca dotychczas obowiązującą ustawę z dnia 8 stycznia 1993 r. ${ }^{23}$ o podatku od towarów i usług oraz o podatku akcyzowym.

18 ETS w wyroku z dnia 26 stycznia 2006 r. (sygn. akt C-533/03) wskazał, że jeżeli akty normatywne są niezbędne dla funkcjonowania rynku wewnętrznego, to zasadniczą kwestią podlegającą badaniu jest wykazanie, czy jedynym lub głównym celem regulacji prawnych jest zbliżanie przepisów ustawodawczych, wykonawczych i administracyjnych państw członkowskich w zakresie podatków, czy też szerzej należałoby rozumieć powyższe rozważania i odnieść je do danin publicznych w ogólności; http://eurlex.europa.eu/LexUriServ/LexUriServ.do?uri=CE LEX:62003J0533:PL:HTML (dostęp: 17.04.2011).

${ }^{19}$ Dz. U. UE. L nr 71, s. 1301 ze zm.

${ }^{20}$ Dz. U. UE L nr 347, s. 1 ze zm.

${ }^{21}$ Por. szerzej na temat procesu harmonizacji podatku od wartości dodanej: A. Rochala, Wspólny system podatku od wartości dodanej w Unii Europejskiej. Opodatkowanie transakcji handlowych w warunkach jednolitego rynku, [w:] E. Piontek, A. Zawidzka (red.), Szkice z prawa Unii Europejskiej, t. II: Prawo materialne, Kraków 2003; A. Bartosiewicz, Efektywność prawa wspólnotowego w Polsce na przykładzie VAT, Warszawa 2009.

${ }_{22}$ Dz. U. z 2004 r. Nr 54, poz. 535, t.j. Dz. U. z 2011 r. Nr 177, poz. 1054 ze zm.

${ }^{23}$ Dz. U. z 1993 r. Nr 11, poz. 50 ze zm. 
Do ustawy z 2004 r., podobnie jak w poprzednio obowiązującej, prawodawca wprowadził instytucję dodatkowego zobowiązania podatkowego określoną w art. 109 ust. 4-8 ustawy o VAT.

W aktualnym stanie prawnym regulacja odnosząca się do dodatkowego zobowiązania podatkowego nie obowiązuje $\mathrm{z}$ uwagi na uchylenie $\mathrm{z}$ dniem 1 grudnia 2008 r. ww. przepisów ${ }^{24}$. Przedmiotowa instytucja daninowa zarówno w trakcie jej funkcjonowania, jak i po jej wyeliminowaniu z obrotu prawnego budzi wiele kontrowersji na gruncie prawa polskiego i unijnego.

Z treści art. 109 ust. 4-8 ustawy o VAT wynika, że dodatkowe zobowiązanie podatkowe było nakładane przez naczelnika urzędu skarbowego lub organ kontroli skarbowej w ściśle określonych w ustawie przypadkach, tj. w sytuacji, gdy:

- podatnik w złożonej deklaracji podatkowej wykazał kwotę zobowiązania podatkowego niższą od kwoty należnej;

- podatnik w złożonej deklaracji podatkowej wykazał kwotę zwrotu różnicy podatku lub zwrotu podatku naliczonego wyższą od kwoty należnej;

- podatnik wykazał w deklaracji podatkowej i otrzymał kwotę zwrotu różnicy podatku lub kwotę zwrotu podatku naliczonego, a powinien wykazać kwotę zobowiązania podatkowego podlegającą wpłacie do urzędu skarbowego;

- podatnik nie złożył deklaracji podatkowej oraz nie wpłacił kwoty zobowiązania podatkowego.

We wszystkich omawianych sytuacjach organ prowadzący postępowanie wyjaśniające w pierwszej kolejności był zobowiązany do określenia w prawidłowej wysokości świadczenia, które zostało nieprawidłowo wskazane przez podatnika w sytuacjach określonych $\mathrm{w}$ art. 109 ust. 4-8 ustawy oraz do wymierzenia dodatkowego zobowiązania podatkowego w wysokości $30 \%$ kwoty zaniżenia powstałego zobowiązania. Ustawodawca w treści art. 109 ust. 4 i 5 wyraźnie wskazał, że organ prowadzący postępowanie ,ustala” dodatkowe zobowiązanie podatkowe. Wykładnia językowa nie pozostawia zatem żadnych wątpliwości o obligatoryjnym nałożeniu na podatnika dodatkowego zobowiązania podatkowego w sytuacjach określonych w art. 109 ust. 4 i 5 oraz poprzez odpowiednie stosowanie ww. przepisów w sytuacjach wskazanych w art. 109 ust. 8 pkt 1 i 2.

Konstrukcja dodatkowego zobowiązania podatkowego określona w art. 109 ustawy o podatku od towarów i usług jako podmioty powstałego stosunku prawnego określała podatnika oraz organ prowadzący postępowanie, natomiast przedmiotem stawała się wysokość zobowiązania podatku od towarów i usług oraz kwota dodatkowego zobowiązania podatkowego. Organy prowadzące postępowanie były więc silnie związane rozwiązaniami ustawowymi i pozbawione prawa uznaniowości w zakresie nakładania dodatkowego zobowiązania podatkowego.

${ }^{24}$ Przepisy art. 109 ust. $4-8$ zostały uchylone przez ustawę z dnia 7 listopada 2008 r., Dz. U. z 2008 r. Nr 209, poz. 1320. 
Dodatkowe zobowiązanie podatkowe stanowiło pewnego rodzaju sankcję za próbę uniknięcia uiszczenia zobowiązania daninowego wynikającego z przepisów prawa, a związanego z prowadzoną działalnością gospodarczą.

Wątpliwości interpretacyjne budził charakter prawny omawianej instytucji dodatkowego zobowiązania podatkowego. Wątpliwości te powstały już na gruncie ustawy z 1993 r. i były podnoszone także na gruncie ustawy z 2004 r. Dodatkowe trudności pojawily się $\mathrm{w}$ zakresie stosowania dodatkowego zobowiązania podatkowego po wstąpieniu Polski w struktury europejskie.

Na przestrzeni lat powstały w zasadzie trzy propozycje interpretacyjne odnoszące się do charakteru prawnego dodatkowego zobowiązania podatkowego. Pierwszy z nich zakładał, że dodatkowe zobowiązanie podatkowe stanowi sankcję karną ${ }^{25}$. Drugi pogląd stanowiła teza, zgodnie z którą dodatkowe zobowiązanie podatkowe jest podatkiem w rozumieniu art. 6 o.p. ${ }^{26}$ Trzecia koncepcja wskazuje natomiast, że dodatkowe zobowiązanie podatkowe jest sankcją o charakterze administracyjnym $^{27}$. Powyższy pogląd zasługuje na akceptację. W doktrynie prawa przez sankcję prawną rozumiano zapowiedź reakcji (w ujęciu normatywnym) lub reakcję ze strony państwa (w ujęciu realistycznym) na zachowanie sprzeczne z normą prawną, skutkującą ujemnymi następstwami dla naruszającego normę $e^{28}$. Do zasadniczych cech sankcji administracyjnej zaliczono konieczność określenia w normie prawnej sytuacji, w jakiej może (nie musi) znaleźć się adresat normy, określenia w normie powinności zachowania się adresata normy i określenia sankcji jako dolegliwości związanej z naruszeniem określonej normy prawnej ${ }^{29}$. Sankcje administracyjne ${ }^{30}$ dzielone są na: sankcje ustrojowe - powiązane $\mathrm{z}$ ustrojem administracji; sankcje proceduralne i egzekucyjne - powiązane $z$ postępowaniem administracyjnym i egzekucyjnym oraz służące jego prawidłowemu przebiegowi; sankcje prawnomaterialne - powiązane z prawem administracyjnym $\mathrm{i}$ jego prawidłowym stosowaniem. W literaturze przedmiotu zaproponowano również doktrynalną definicję sankcji administracyjnej, rozumianej jako nakładane w drodze aktu stosowania prawa przez organ administracji publicznej, wynikające ze stosunku administracyjnoprawnego ujemne (niekorzystne) skutki dla podmiotów prawa, które nie stosują się do obowiązków wynikających z norm prawnych lub aktów stosowania prawa ${ }^{31}$.

25 Por. szerzej: A. Hanusz, Charakter dodatkowego zobowiązania podatkowego w podatku od towarów i ustug, „Przegląd Podatkowy” 2000, nr 11, s. 3 i n.

${ }^{26}$ Por. szerzej: I. Ożóg, Czy sankcja VAT jest zgodna z prawem?, „Prawo i Podatki” 2005, nr 12 , s. 3 i n.

27 T. Michalik, Dodatkowe zobowiazanie w ustawie o VAT-uwagi w sprawie zgodności art. 109 ust. 4-8 ustawy z przepisami Dyrektywy 2006/112, „Monitor Podatkowy” 2007, nr 10, s. 7 i n.

28 P. Majka, Sankcje w prawie podatkowym, Warszawa 2011, s. 41.

29 R. Hauser, Z. Niewiadomski, A. Wróbel (red.), System Prawa Administracyjnego. Prawa administracyjne materialne, t. 7, Warszawa 2012, s. 628.

30 Ibidem, s. 636.

31 M. Wincenciak, Sankcje w prawie administracyjnym i procedura ich wymierzania, Warszawa 2008 , s. 73 . 
Na gruncie powyższych rozważań dodatkowe zobowiązanie podatkowe wynikające z ustawy o podatku od towarów i usług stanowi prawnomaterialną sankcję administracyjną.

Za stanowiskiem uznającym dodatkowe zobowiązanie podatkowe za sankcję administracyjną opowiedział się Trybunał Konstytucyjny w wyroku z dnia 29 kwietnia 1998 r. ${ }^{32}$ Jednocześnie skład orzekający Trybunału Konstytucyjnego podkreślił, że w demokratycznym państwie prawa nie może dojść do sytuacji, w której odpowiedzialność administracyjna (z tytułu sankcji administracyjnej, jaką jest dodatkowe zobowiązanie podatkowe) będzie zbiegać się z odpowiedzialnością karnoskarbową (z tytułu wykroczenia skarbowego). Przyjęta przez Trybunał Konstytucyjny koncepcja dodatkowego zobowiązania podatkowego, określonego w ustawie z 1993 r., jako sankcji administracyjnej znalazła również wyraz w wyroku Trybunału Konstytucyjnego z dnia 4 września 2007 r. ${ }^{33}$ wydanym na gruncie rozwiązań ustawy z 2004 r. W omawianym orzeczeniu Trybunału Konstytucyjnego potwierdzono zasadnicze tezy orzeczenia z $1998 \mathrm{r}$. kwalifikujące dodatkowe zobowiązanie podatkowe jako sankcję administracyjną. Również Naczelny Sąd Administracyjny w uchwale składu siedmiu sędziów z dnia 16 listopada 2009 r. ${ }^{34}$ zaakcentował, że „,dodatkowe zobowiązanie podatkowe stanowi sankcję administracyjną w postaci kary pieniężnej za delikt administracyjny".

Uznanie dodatkowego zobowiązania podatkowego za sankcję administracyjną jednocześnie pozwala uznać tę instytucję za niepodatkową należność budżetu państwa, a w konsekwencji powyższego rodzi pytanie o możliwość nakładania tego rodzaju świadczeń publicznoprawnych $\mathrm{w}$ zgodzie $\mathrm{z}$ rozwiązaniami prawa unijnego, a w szczególności dyrektywy 2006/112/WE ${ }^{35}$.

Zagadnienie zgodności instytucji dodatkowego zobowiązania podatkowego z rozwiązaniami unijnymi stało się przedmiotem analizy Trybunału Sprawiedliwości Wspólnot Europejskich na skutek pytania prejudycjalnego zadanego przez Naczelny Sąd Administracyjny w postanowieniu z dnia 31 lipca 2007 r. ${ }^{36}$ Pytanie prejudycjalne zostało zadane na gruncie stanu prawnego w czasie obowiązywania

${ }^{32}$ Sygn. akt K 17/97, LEX nr 32905.

33 Sygn. akt P 43/06, LEX nr 316027.

${ }^{34}$ Sygn. akt I FPS 2/09, baza orzeczeń strony internetowej Naczelnego Sądu Administracyjnego: www.nsa.gov.pl (dostęp: 16.03.2012).

${ }^{35} \mathrm{Na}$ marginesie powyższych rozważań należy zaznaczyć, iż zagadnienie zgodności polskich rozwiązań dotyczących dodatkowego zobowiązania podatkowego z prawem unijnym było przedmiotem dyskusji w doktrynie i praktyce prawa finansowego, por. np. K. Lasiński-Sulecki, Dodatkowe zobowiqzanie podatkowe w VAT - próba oceny zgodności z europejskim prawem wspólnotowym, „Przegląd Podatkowy” 2006, nr 5; M. Olejnik, Uznanie dodatkowego zobowiazania w podatku VAT za sankcję administracyjna, „Przegląd Podatkowy” 2006, nr 7; D. Dudra, T. Burczyński, Sankcje w podatku od towarów i ustug a prawo wspólnotowe, „Przegląd Podatkowy” 2006, nr 8.

${ }^{36}$ Sygn. akt I FSK 1062/06, baza orzeczeń strony internetowej Naczelnego Sądu Administracyjnego: www.nsa.gov.pl (dostęp: 18.03.2012). 
VI dyrektywy $\mathrm{VAT}^{37}$, niemniej jednak wartość merytoryczna rozstrzygnięć pozostaje aktualna na gruncie obecnie obowiązującej dyrektywy 2006/112/WE i rozwiązań dotyczących wprowadzenia szczególnych środków stanowiących odstępstwo od przepisów ww. dyrektywy w celu zapobiegania niektórym formom uchylania się od opodatkowania lub unikania opodatkowania, o jakich mowa w art. 395 cytowanej wyżej dyrektywy.

Trybunał Sprawiedliwości Wspólnot Europejskich w wyroku z dnia 15 stycznia 2009 r. ${ }^{38}$ W sposób jednoznaczny rozstrzygnął kwestię zgodności funkcjonowania instytucji dodatkowego zobowiązania podatkowego $\mathrm{z}$ prawem unijnym. Skład orzekający wskazał, że nie ma przeszkód, by państwo członkowskie przewidziało w swym ustawodawstwie sankcję administracyjną, która może być nakładana na podatników podatku VAT, taką jak dodatkowe zobowiązanie podatkowe przewidziane w art. 109 ust. 5 i 6 polskiej ustawy o podatku od towarów i usług. Jednocześnie Trybunał wskazał, że dodatkowe zobowiązanie podatkowe nie może być uznane za podatek od towarów i usług, ponieważ nie posiada zasadniczych cech tego podatku. Trybunał wskazał również, że sankcja administracyjna określona $\mathrm{w}$ przepisach ustawy o podatku od towarów i usług nie stanowi specjalnych środków stanowiących odstępstwo, mających na celu zapobieganie niektórym rodzajom oszustw podatkowych lub unikaniu opodatkowania, a jako taka może nadal funkcjonować w ramach krajowego systemu prawnego, ponieważ nie stwierdzono niezgodności z prawem unijnym. Cytowane orzeczenie Trybunału rozwiało wątpliwości pojawiające się w orzecznictwie i doktrynie w zakresie zarówno zgodności omawianej instytucji z prawem unijnym, jak i charakteru prawnego dodatkowego zobowiązania podatkowego.

Powyższe rozstrzygnięcie stało się podstawą wydania wyroku przez Naczelny Sąd Administracyjny w sprawie, w której skierowano pytanie prejudycjalne. W orzeczeniu z dnia 20 maja 2009 r. ${ }^{39}$ skład orzekający powtórzył zasadnicze tezy rozstrzygnięcia Trybunału Sprawiedliwości Wspólnot Europejskich.

${ }^{37}$ Wskazać należy, iż pierwsze pytanie prejudycjalne w sprawie oceny zgodności dodatkowego zobowiązania podatkowego z prawem unijnym zostało złożone przez Wojewódzki Sąd Administracyjny postanowieniem z dnia 15 lutego 2006 r. (sygn. akt I SA/Łd 1089/05), jednakże Trybunał Sprawiedliwości postanowieniem z dnia 6 marca 2007 r. (sygn. akt C-168/06) odmówił udzielenia odpowiedzi na pytanie, ponieważ sprawą objęty był okres rozliczeniowy sprzed przystąpienia Polski do struktur europejskich.

${ }^{38}$ Sygn. akt C-502/07, LEX nr 469620.

${ }^{39}$ Sygn. akt I FSK 292/09, baza orzeczeń strony internetowej Naczelnego Sądu Administracyjnego: www.nsa.gov.pl (dostęp: 18.03.2012). 


\section{Podsumowanie}

Wstąpienie Polski w struktury europejskie, obok beneficjów płynących z członkostwa w Unii Europejskiej, nałożyło na polskiego ustawodawcę szereg obowiązków wynikających z pierwotnego i wtórnego prawa unijnego. Zasadniczym obowiązkiem było zharmonizowanie przepisów polskiego prawa danin publicznych, które mogły mieć wpływ na ustanowienie i funkcjonowanie rynku wewnętrznego, a w jego ramach swobód: przepływu towarów, osób, usług i kapitału oraz uniknięcie zakłóceń konkurencji. Harmonizacja polskich rozwiązań prawnych w zakresie prawa daninowego powinna objąć nie tylko regulacje odnoszące się - jak to wskazują postanowienia traktatowe - do świadczeń publicznoprawnych, takich jak podatki, opłaty czy cła, lecz do wszelkich świadczeń publicznoprawnych - podatkowych i niepodatkowych, których wprowadzenie może skutkować naruszeniem swobód traktatowych, instytucji wolnego rynku czy swobody konkurencji.

Casus dodatkowego zobowiązania podatkowego w ustawie o VAT stanowi przykład wpływu prawa unijnego na krajowe prawo daniowe i krajowe instytucje prawnofinansowe. Regulacje unijne odnoszą się nie tylko do podatków, lecz także do niepodatkowych należności budżetowych, takich jak dodatkowe zobowiązanie podatkowe czy ponoszone w ramach Wspólnej Polityki Rolnej opłaty wyrównawcze związane ze wspólną organizacją rynku cukrów.

Wprowadzanie do systemu prawnego instytucji prawnych nieznanych Unii Europejskiej rodzi na ustawodawcy obowiązek przeprowadzenia analiz i badań pod kątem zgodności projektowanej instytucji z rozwiązaniami unijnymi, jeżeli ona dotyczy lub może dotyczyć obszarów objętych kompetencjami Unii Europejskiej.

Mając powyższe na uwadze, prawodawca w zakresie prawa daninowego powinien dochować szczególnej staranności w zakresie przyjmowania aktów normatywnych i wprowadzania instytucji prawnych, aby nie dopuścić do sytuacji, w której doszłoby do naruszenia realizacji zasadniczych celów funkcjonowania Unii Europejskiej i instytucji temu służących. 